\title{
Penerapan Model Application of Step Instruction and Elaboration (APPOSITE) untuk Meningkatkan Hasil Belajar Kognitif Siswa SMA pada Materi Suhu dan Kalor
}

\author{
Nur Kamila ${ }^{1}$, Sri Handono Budi Prastowo ${ }^{2}$, Lailatul Nuraini ${ }^{3}$ \\ 1,2,3 Program Studi Pendidikan Fisika, Universitas Jember \\ e-mail: \\ 1 nur.kamila998@gmail.com \\ 2 srihandono.fkip@unej.ac.id \\ 3 lailatul.fkip@unej.ac.id
}

\begin{abstract}
.
This study aims to determine the differences in the improvement of cognitive learning outcomes of students using the APPOSITE model and students using the direct instruction model. This research is an experimental study with a pretest-posttest control group design. The research subjects were students of class XI IPA at SMA Muhammadiyah 3 Jember. The sample in this study were students of class XI IPA 1 as the experimental class and class XI IPA 2 as the control class. Data collection techniques are carried out through tests, observation, interviews and documentation. The data analysis technique used the N-gain test and t-test. Based on the results of the N-gain analysis, it can be seen that the class that uses the APPOSITE model gets a score of 0.36 in the moderate category, while the N-gain class that uses the direct instruction model gets a score of 0.22 in the low category. Based on the results of bypothesis testing using the independent sample t-test can be concluded that there is a significant difference between the increase in cognitive learning outcomes of students using the APPOSITE learning model and the improvement of student cognitive learning outcomes using the direct instruction learning model.
\end{abstract}

Keyword: APPOSITE model, cognitif learning outcomes

\begin{abstract}
ABSTRAK.
Penelitian ini bertujuan untuk mengetahui perbedaan peningkatan hasil belajar kognitif siswa yang menggunakan model APPOSITE dengan siswa yang menggunakan model direct instruction. Penelitian ini merupakan penelitian eksperimen dengan desain Pretest-Posttest Control Group Design. Subjek penelitiannya adalah siswa kelas XI IPA di SMA Muhammadiyah 3 Jember. Sampel dalam penelitian ini adalah siswa kelas XI IPA 1 sebagai kelas eksperimen dan siswa kelas XI IPA 2 sebagai kelas kontrol. Teknik pengumpulan data dilakukan melalui tes, observasi, wawancara dan dokumentasi. Teknik analisis data menggunakan uji $N$-gain dan uji t-test. Berdasarkan hasil analisis $N$-gain terlihat bahwa kelas yang menggunakan model APPOSITE memperoleh skor 0,36 dengan kategori sedang, sedangkan $N$-gain kelas yang menggunakan model direct instruction memperoleh skor 0,22 dengan kategori rendah. Berdasarkan hasil uji hipotesis menggunakan uji independent sample t-test dapat disimpulkan bahwa terdapat perbedaan yang signifikan antara peningkatan hasil belajar kognitif siswa yang menggunakan model pembelajaran APPOSITE dengan peningkatan hasil belajar kognitif siswa yang menggunakan model pembelajaran direct instruction.
\end{abstract}

Kata kunci: model APPOSITE, hasil belajar kognitif 


\section{PENDAHULUAN}

Ilmu Pengetahuan Alam (IPA) merupakan salah satu ilmu pengetahuan yang ikut berperan penting dalam perkembangan dan kemajuan IPTEK. Fisika adalah salah satu bagian dari IPA yang mempelajari fenomena alam beserta gejalanya yang terdiri dari proses dan produk (Indrawati., 2011). Proses adalah langkah-langkah pengamatan ilmiah yang dilakukan siswa ketika proses pembelajaran dalam rangka menemukan sebuah produk, sedangkan produk adalah hasil pengamatan yang berupa fakta, konsep, prinsip, prosedur, teori, dan hukum (Indrawati, 2013). Menurut Permendikbud Nomor 54 Tahun 2013 tentang standar kelulusan SMA disebutkan bahwa ilmu fisika adalah salah satu bagian dari IPA yang memiliki tujuan agar siswa diharapkan memiliki pengetahuan faktual dan konseptual yang berdasarkan rasa ingin tahu tentang ilmu pengetahuan fisika, terkait penyebab fenomena dan kejadian untuk memecahkan masalah. Berdasarkan uraian yang telah dijelaskan dapat disimpulkan bahwa fisika adalah ilmu yang tidak hanya mempelajari angka-angka maupun rumus dan persamaan-persamaan yang harus dihafalkan, melainkan fisika juga harus dipelajari dengan memahami konsep dasar dalam penyelesaian masalah dengan kehidupan nyata(Nurwianti et al., 2019)

Tujuan pembelajaran fisika adalah melatih siswa untuk bisa menguasai konsep, dengan begitu siswa akan lebih mudah mengembangkan pengetahuan dan mengaplikasikannya dalam kehidupan nyata yang akan meningkatkan keterampilan dan sikap siswa (Prihandono, 2011). Sehingga, dalam belajar fisika tidak cukup hanya belajar dari buku saja atau mendengar penjelasan dari guru maupun orang lain, melainkan haruslah ada aspek keterampilan supaya siswa terlatih dalam menemukan konsep sendiri. Menurut Pratama, (2014), proses pembelajaran IPA harus lebih menekankan pada katerampilan proses sains yang dimiliki siswa, karena umumnya IPA dipahami sebagai ilmu yang lahir dan berkembang melalui langkah-langkah observasi atau pengamatan. Oleh karena itu, keterampilan proses sains siswa perlu dikembangkan agar siswa terlatih dalam menemukan konsep sendiri, dengan begitu dapat melatih siswa berpikir kritis dan melatih siswa dalam mengembangkan pola pikir melalui metode ilmiah. Pendekatan keterampilan proses sains dapat meningkatan hasil belajar IPA fisika (Azizirrahim et al., 2017).

Namun realita dari guru-guru fisika dalam pembelajaran masih jarang memperhatikan keterampilan proses sains tapi lebih sering menerapkan model pembelajaran yang masih berpusat pada guru sedangkan siswa hanya menerima informasi dari guru. Berawal dari berbagai pengalaman belajar, bahwasannya pelajaran fisika dikenal sebagai pelajaran yang sulit dipahami, paling ditakuti dan tidak disukai oleh siswa, karena pelajaran fisika merupakan pelajaran yang berat dan serius yang tidak jauh dari persoalan konsep matematis dan penyelesaian soal-soal yang mengandung rumus-rumus rumit. Pernyataan tersebut sesuai dengan pendapat Abdurrahman et al., (2011), yang menyatakan bahwa siswa tidak meminati pelajaran fisika karena mereka berpandangan buruk pada fisika dan menganggap fisika itu sebagai pelajaran yang sulit dipahami.

Berdasarkan hasil wawancara dengan salah satu guru mata pelajaran fisika di SMA Muhammadiyah 3 Jember, diketahui bahwa model pembelajaran yang sering digunakan adalah model pembelajaran direct instruction dengan metode ceramah, tanya jawab, dan tugas. Peneliti juga memperoleh informasi dari hasil wawancara bahwasannya hasil belajar fisika siswa masih tergolong rendah dibandingkan dengan mata pelajaran lainnya. Hal ini dikarenakan beberapa faktor yang salah satunya dalam proses pembelajaran di kelas guru cenderung menerapkan pembelajaran yang masih berpusat pada guru (teacher centered) sehingga menyebabkan pemahaman sebagian besar siswa terhadap pelajaran khususnya pelajaran fisika tidak maksimal yang akhirnya hasil belajar fisika mereka masih tergolong rendah. Rendahnya hasil belajar siswa dapat dipengaruhi oleh beberapa faktor diantaranya adalah siswa masih menganggap bahwa fisika adalah pelajaran yang sulit, media pembelajaran yang digunakan guru kurang bervariasi, model dan metode yang digunakan guru kurang inovatif, dan kurangnya interaksi antara guru dengan siswa saat proses pembelajaran (Jannah et al., 2019). 
Faktor lain yang mempengaruhi hasil belajar siswa adalah tidak semua materi yang disampaikan pendidik dapat diterima peserta didik dengan baik. Hal ini dikarenakan penyampaian materi cenderung terfokus pada guru (teacher centered) yang mengakibatkan peserta didik kurang mengembangkan potensinya dalam proses pembelajaran di kelas. Sehingga tujuan pembelajaran yang diharapkan jauh dari kata tercapai (Soni et al., 2014). Seharusnya dalam proses pembelajaran yang baik adalah proses pembelajaran yang cenderung terfokus pada siswa (student centered) dan guru sebagai fasilitator dalam pembelajaran. Karena menurut Ariyanti, (2013), proses pembelajaran yang berpusat pada siswa (student centered) seperti kegiatan praktikum dapat membantu peserta didik untuk meningkatkan hasil belajar.

Berdasarkan uraian yang telah dijelaskan, salah satu model pembelajaran yang mampu meningkatkan hasil belajar kognitif siswa adalah model pembelajaran APPOSITE (Application of Step Instruction and Elaboration). Karena menurut Prastowo, (2019) desain dari model APPOSITE merupakan pengembangan dari model pembelajaran learning gycle 5E. Pembelajaran IPA dengan model siklus belajar (learning gycle $5 \mathrm{E}$ ) dengan eksperimen dapat meningkatkan hasil belajar siswa (Astutik, 2012). Model APPOSITE merupakan model pembelajaran yang menekankan pada penerapan instruksi bertahap (step instruction) dalam bentuk elaborasi (Prastowo, 2019). Maksud dari step instruction dalam model pembelajaran APPOSITE adalah tahapan berupa pertanyaan yang dapat mendorong siswa untuk menjawab pertanyaan dari sebuah permasalahan secara bertahap menuju ke arah jawaban utama permasalahan. Dalam model pembelajaran APPOSITE guru hanya sebagai fasilitator yang akan menyiapkan instruksi bertahap untuk mendukung proses pembelajaran siswa.

Pendekatan yang digunakan dalam model APPOSITE adalah pendekatan kontekstual yang didasari atas pandangan teori konstruktivisme dengan unsur penting pengetahuan awal dan instruksi betahap karena menurut pandangan teori konstruktivisme, siswa dibentuk secara aktif dan dapat menemukan sendiri pengetahuannya dalam pembelajaran. Adapun tahapan dalam pembelajaran model APPOSITE adalah tahap invitasi, tahap eksplorasi, tahap elaborasi, tahap penjelasan dan solusi, tahap pengambilan dan tindakan, tahap pengujian dan evaluasi, serta tahap refleksi diri (Prastowo, 2019). Apabila tahapan-tahapan tersebut diterapkan dalam proses pembelajaran dengan benar, maka dapat meningkatkan hasil belajar kognitif siswa. Karena pada tahap invitasi, eksplorasi, elaborasi, serta penjelasan dan solusi dapat melatih keterampilan proses sains siswa menjadi lebih baik. Jadi, apabila keterampilan proses sains siswa baik maka hasil belajar siswa akan menjadi lebih baik. Sesuai penelitian yang dilakukan oleh Azizirrahim, bahwasannya pendekatan keterampilan proses sains dalam pembelajaran dapat meningkatan hasil belajar IPA fisika (Azizirrahim et al., 2017). Sedangkan model direct instruction merupakan model pembelajaran yang menekankan penyampaian materi dilakukan secara verbal oleh guru kepada peserta didik (Zahriani, 2014). Berdasarkan uraian yang telah dijelaskan maka tujuan dari penelitian ini adalah mengkaji perbedaan peningkatan hasil belajar kognitif siswa yang melakukan pembelajaran menggunakan model APPOSITE dengan siswa yang melakukan pembelajaran dengan model directct instruction.

\section{METODOLOGI}

Penelitian ini termasuk dalam jenis penelitian eksperimen dengan desain pretest-posttest control group design. Penentuan tempat penelitian menggunakan metode purposive sampling area yang artinya penentuan tempat dipilih dengan sengaja berdasarkan tujuan dan pertimbangan tertentu. Tempat penelitian ini di SMA Muhammadiyah 3 Jember dengan populasi seluruh kelas XI IPA di SMA Muhammadiyah 3 Jember pada semester ganjil tahun ajaran 2019/2020. Sedangkan sampel dalam penelitian ini diambil dari salah satu kelas XI IPA di SMA Muhammadiyah 3 Jember dengan membentuk dua kelas yaitu kelas eksperimen dan kelas kontrol. 
Sebelum membentuk kelas, dilakukan uji homogenitas terlebih dahulu dengan bantuan program SPSS 23 dengan data nilai ulangan harian siswa pada materi sebelumnya. Jika kelas sudah homogen, maka penentuan sampel menggunakan metode cluster random sampling dengan teknik undian dan diperoleh dua kelas yaitu kelas XI IPA 1 sebagai kelas eksperimen dan kelas XI IPA 2 sebagai kelas kontrol. Kelas eksperimen diberi perlakuan dengan menggunakan model APPOSITE sedangkan kelas kontrol diberi perlakuan dengan menggunakan model direct instruction. Sebelum diberikan perlakuan, siswa dalam kelas eksperimen dan kelas kontrol diberikan soal pre-test untuk mengetahui kemampuan awal siswa, kemudian kedua kelas mendapatkan perlakuan sesuai yang telah direncanakan selama tiga kali pertemuan. Setelah pemberian perlakuan, kedua kelas tersebut diberikan soal post-test untuk mengetahui hasil belajar siswa.

Adapun langkah-langkah penelitian yang dilakukan dalam penelitian ini diantaranya yang pertama adalah melakukan persiapan dengan menyiapkan surat pengantar penelitian dari pihak fakultas, kemudian menentukan populasi, setelah itu melakukan wawancara dengan salah satu guru mata pelajaran fisika di SMA Muhammadiyah 3 Jember dan mengambil data awal berupa daftar nama dan data nilai ulangan harian pada materi sebelumnya untuk diuji homogenitas, dari hasil uji homogenitas kemudian dapat diambil sampel sebagai kelas eksperimen dan kelas kontrol dengan metode cluster random sampling, kemudian melaksanakan pre-test pada kedua kelas untuk mengetahui kemampuan awal siswa.

Setelah pre-test dilakukan, langkah selanjutnya adalah melaksanakan pembelajaran pada kelas eksperimen menggunakan model APPOSITE yang diajarkan oleh peneliti sedangkan kelas kontrol menggunakan model direct instruction yang diajarkan oleh guru fisika di SMA Muhammadiyah 3 Jember, setelah itu dilakukanlah post-test pada akhir pembelajaran untuk mengetahui hasil belajar siswa setelah diberi perlakuan, dan setelah itu peneliti melakukan wawancara dengan salah satu siswa kelas eksperimen untuk mengetahui tanggapan siswa terkait model pembelajaran yang diterapkan di kelas, selanjutnya peneliti menganalisis data yang telah diperoleh dari hasil penelitian dan membuat pembahasan serta membuat kesimpulan.

Jenis data hasil belajar kognitif yang digunakan dalam penelitian ini adalah data interval berupa tes kognitif dengan soal uraian. Aspek hasil belajar yang dinilai dalam penelitian ini meliputi aspek memahami (C2), menerangkan (C3), menganalisis (C4), mengevaluasi (C5), dan mencipta (C6). Sebelum menentukan perbedaan peningkatan hasil belajar siswa, teknik analisis data hasil belajar siswa dianalisis dengan rumus sebagai berikut.

Nilai hasil belajar siswa $=\frac{\text { skor yang diperoleh siswa }}{\text { skor maksimum }} \times 100$

Setelah menentukan nilai hasil belajar siswa, kemudian mencari nilai peningkatan pada hasil belajar kognitif siswa kelas eksperimen dan kelas kontrol menggunakan uji $N$-gain. Perhitungan $\mathrm{N}$-gain menggunakan rumus sebagai berikut.

$$
\langle g\rangle=\frac{\left\langle S_{\text {post }}\right\rangle-\left\langle S_{\text {pre }}\right\rangle}{\left\langle S_{\text {max }}\right\rangle-\left\langle S_{\text {pre }}\right\rangle}
$$

dengan:

$\langle g\rangle \quad$ : peningkatan hasil belajar kognitif siswa

$\left\langle S_{\text {post }}\right\rangle$ : skor rata-rata post-test

$\left\langle S_{\text {pre }}\right\rangle$ : skor rata-rata pre-test

$\left\langle S_{\text {max }}\right\rangle$ : skor maksimum yang diperoleh siswa

Berdasarkan hasil perhitungan nilai $N$-gain tersebut kemudian dapat diambil kesimpulan sesuai dengan kategori tingkat $N$-gain pada Tabel 1. berikut. 
Tabel 1. Kategori tingkat $\mathbf{N}$-gain

\begin{tabular}{cc}
\hline Nilai $\boldsymbol{N}$-Gain $(\mathrm{g})$ & Kategori \\
\hline$\langle\boldsymbol{g}\rangle \geq \mathbf{0 , 7}$ & Tinggi \\
\hline $\mathbf{0 , 7}>\langle\boldsymbol{g}\rangle \geq \mathbf{0 , 3}$ & Sedang \\
\hline$\langle\boldsymbol{g}\rangle\langle\mathbf{0 , 3}$ & Rendah \\
\hline
\end{tabular}

(Hake, 1999)

Perbedaan peningkatan hasil belajar kognitif siswa yang menggunakan model APPOSITE dengan peningkatan hasil belajar kognitif siswa yang menggunakan model direct instruction dapat dilakukan dengan uji t-test dengan data post-test pada kelas eksperimen dan kelas kontrol. Sebelum dilakukan uji $t$-test data harus diuji normalitasnya terlebih dahulu untuk mengetahui apakah data tersebut telah terdistribusi normal atau tidak. Apabila data terdistribusi normal maka dilakukan uji independent sample t-test, namun jika data tidak terdistribusi normal maka dilakukan uji nonparametric Mann-Whitney U.

\section{TEMUAN DAN PEMBAHASAN}

Tujuan dari penelitian ini adalah mengkaji perbedaan peningkatan pada hasil belajar kognitif siswa yang menggunakan model APPOSITE dengan hasil belajar kognitif siswa yang menggunakan model direct instruction. Sebelum melakukan pembelajaran, siswa kelas eksperimen dan kelas kontrol sama-sama diberikan soal pre-test untuk mengetahui kemampuan awal siswa. Setelah kedua kelas diberikan soal pre-test kemudian diberi perlakuan dengan menerapkan model APPOSITE pada kelas eksperimen dan model direct instruction pada kelas kontrol dengan pelaksanaan pembelajaran tiga kali pertemuan, kemudian dilakukan post-test pada kedua kelas untuk melihat hasil belajar kognitif siswa. Data hasil belajar siswa kelas eksperimen dan kelas kontrol didapat dari hasil penilaian aspek kognitif siswa pada pre-test dan post-test. Hasil pre-test dan post-test pada kelas eksperimen dan kelas kontrol dapat dilihat pada Tabel 2. berikut.

Tabel 2. Hasil pre-test dan post-test kelas eksperimen dan kelas kontrol

\begin{tabular}{lcccc}
\hline \multirow{2}{*}{ Komponen } & \multicolumn{2}{c}{ Kelas Eksperimen } & \multicolumn{2}{c}{ Kelas Kontrol } \\
\cline { 2 - 5 } & Pre-Test & Post-Test & Pre-Test & Post-Test \\
\hline Jumlah siswa & 30 & 30 & 27 & 27 \\
\hline Nilai tertinggi & 60 & 77 & 57 & 66 \\
\hline Nilai terendah & 20 & 49 & 20 & 34 \\
\hline Rata-rata & $\mathbf{4 2 , 2 0}$ & $\mathbf{6 2 , 9 3}$ & $\mathbf{3 8 , 7 0}$ & $\mathbf{5 2 , 0 4}$ \\
\hline
\end{tabular}

Berdasarkan hasil analisis Tabel 2. diketahui bahwa nilai rata-rata pre-test kelas eksperimen lebih tinggi daripada nilai rata-rata pre-test kelas kontrol. Namun nilai rata-rata pre-test pada kedua kelas tersebut tidak jauh berbeda, sehingga dapat disimpulkan bahwa kedua kelas tersebut memiliki kemampuan awal yang sama atau homogen. Berdasarkan Tabel 2. terlihat bahwa nilai rata-rata post-test kelas eksperimen juga lebih tinggi daripada nilai rata-rata post-test kelas kontrol.

Sebelum mengambil keputusan bahwa terdapat perbedaan signifikan antara peningkatan hasil belajar kognitif siswa yang menggunakan model APPOSITE dengan peningkatan hasil belajar kognitif siswa yang menggunakan model direct instruction maka sebelumnya dilakukan uji $N$-gain untuk mengetahui nilai peningkatan hasil belajar siswa pada kelas eksperimen dan kelas kontrol dengan data nilai pre-test dan post-tes pada masing-masing kelas. Hasil perhitungan menggunakan uji $N$-gain yang diperoleh pada siswa kelas eksperimen dapat dilihat pada Tabel 3. berikut. 
Tabel 3. Hasil $\mathbf{N}$-gain kelas eksperimen

\begin{tabular}{lccccc}
\hline \multicolumn{1}{c}{ Komponen } & Pre-Test & Post-Test & Selisih & $\langle\boldsymbol{g}\rangle$ & Kriteria \\
\hline Rata-rata & 42,20 & 62,93 & & & \\
\cline { 1 - 3 } Nilai Tertinggi & 60 & 77 & 20,73 & 0,36 & Sedang \\
\cline { 1 - 3 } Nilai Terendah & 20 & 49 & & & \\
\hline
\end{tabular}

Berdasarkan hasil analisis data pada Tabel 3. menunjukkan bahwa nilai rata-rata pre-test dan post-test kelas eksperimen adalah 42,20 dan 62,93. Selisih dari nilai pre-test dan post-test tersebut sebesar 20,37. Untuk mengetahui peningkatan hasil belajar siswa dapat dilihat pada nilai $N$-gain yaitu 0,36. Menurut kategori yang telah ditentukan, nilai 0,36 berada pada rentang nilai interval $0,7\rangle\langle g\rangle \geq 0,3$ yang artinya nilai 0,36 termasuk dalam kategori sedang. Hal ini menandakan bahwa adanya peningkatan hasil belajar siswa setelah diterapkannya model APPOSITE dengan kategori sedang. Adapun hasil perhitungan $N$-gain yang diperoleh pada siswa kelas kontrol dapat dilihat pada Tabel 4. sebagai berikut.

Tabel 4. Hasil $N$-gain kelas kontrol

\begin{tabular}{lccccc}
\hline \multicolumn{1}{c}{ Komponen } & Pre-Test & Post-Test & Selisih & $\langle\boldsymbol{g}\rangle$ & Kriteria \\
\cline { 1 - 3 } Rata-rata & 38,70 & 52,04 & & & \\
\cline { 1 - 3 } Nilai Tertinggi & 57 & 66 & \multirow{2}{*}{13,34} & 0,22 & Rendah \\
\cline { 1 - 3 } Nilai Terendah & 20 & 34 & & & \\
\hline
\end{tabular}

Berdasarkan hasil analisis pada Tabel 4. menunjukkan bahwa nilai rata-rata pre-test dan posttest kelas kontrol adalah 38,70 dan 52,04. Selisih dari nilai pre-test dan post-test tersebut sebesar 13,34. Untuk mengetahui peningkatan hasil belajar siswa dapat dilihat pada nilai gain yaitu 0,22. Menurut kategori yang telah ditentukan, nilai 0,22 berada pada rentang nilai interval $\langle g\rangle<0,3$ yang artinya nilai 0,22 termasuk dalam kategori rendah. Hal ini menandakan bahwa hasil belajar siswa yang menggunakan model direct instruction juga mengalami peningkatan namun dalam kategori rendah.

Adapun dalam mengambil keputusan bahwa terdapat perbedaan signifikan antara peningkatan hasil belajar kognitif siswa yang menggunakan model APPOSITE dengan peningkatan hasil belajar kognitif siswa yang menggunakan model direct instruction dapat dilakukan uji $t$-test dengan bantuan program SPSS. Sebelum dilakukan uji t-test data harus diuji normalitas terlebih dahulu menggunakan uji one-sample kolmogorov-smirnov test. Berdasarkan hasil uji kolmogorovsmirnov test data hasil belajar siswa kelas eksperimen dan kelas kontrol diperoleh nilai Asymp. Sig. (2-tailed) sebesar 0,200 dan 0,080 yang lebih besar dari taraf signifikan yaitu 0,05 sehingga dapat disimpulkan bahwa data tersebut berdistribusi normal, sehingga dapat dilakukan uji independent sample t-test.

Pada penelitian ini untuk melakukan uji perbedaan signifikan antara peningkatan hasil belajar kognitif siswa yang menggunakan model APPOSITE dengan peningkatan hasil belajar kognitif siswa yang menggunakan model direct instruction diajukan hipotesis statistik untuk diuji menggunakan independent sample t-test dengan bantuan SPSS 23. Berikut merupakan hipotesis statistik dalam penelitian ini:

$\mathrm{H}_{0}$ : peningkatan hasil belajar kognitif siswa yang menggunakan model APPOSITE sama dengan peningkatan hasil belajar kognitif siswa yang menggunakan model direct instruction

$\mathrm{H}_{\mathrm{a}}$ : peningkatan hasil belajar kognitif siswa yang menggunakan model APPOSITE berbeda dengan peningkatan hasil belajar kognitif siswa yang menggunakan model direct instruction

Berdasarkan hasil uji independent sample t-test diperoleh nilai sig. (2-tailed) sebesar 0,000 dan nilai tersebut lebih kecil dari taraf signifikan yaitu 0,05 . Menurut pedoman dalam pengambilan keputusan, jika signifikansi (sig.) $\leq 0,05$ maka $\mathrm{H}_{0}$ ditolak dan $\mathrm{H}_{\mathrm{a}}$ diterima (Sugiyono, 2014). 
Berdasarkan hasil uji independent sample t-test dapat diambil keputusan bahwa $\mathrm{H}_{0}$ ditolak dan $\mathrm{H}_{\mathrm{a}}$ diterima yang artinya terdapat perbedaan yang signifikan antara peningkatan hasil belajar kognitif siswa yang menggunakan model APPOSITE dengan peningkatan hasil belajar kognitif siswa yang menggunakan model direct instruction. Perbedaan peningkatan hasil belajar kognitif siswa yang menggunakan model APPOSITE pada kelas eksperimen dan peningkatan hasil belajar kognitif siswa yang menggunakan model direct instruction pada kelas kontrol dapat dilihat pada Gambar 1 berikut.

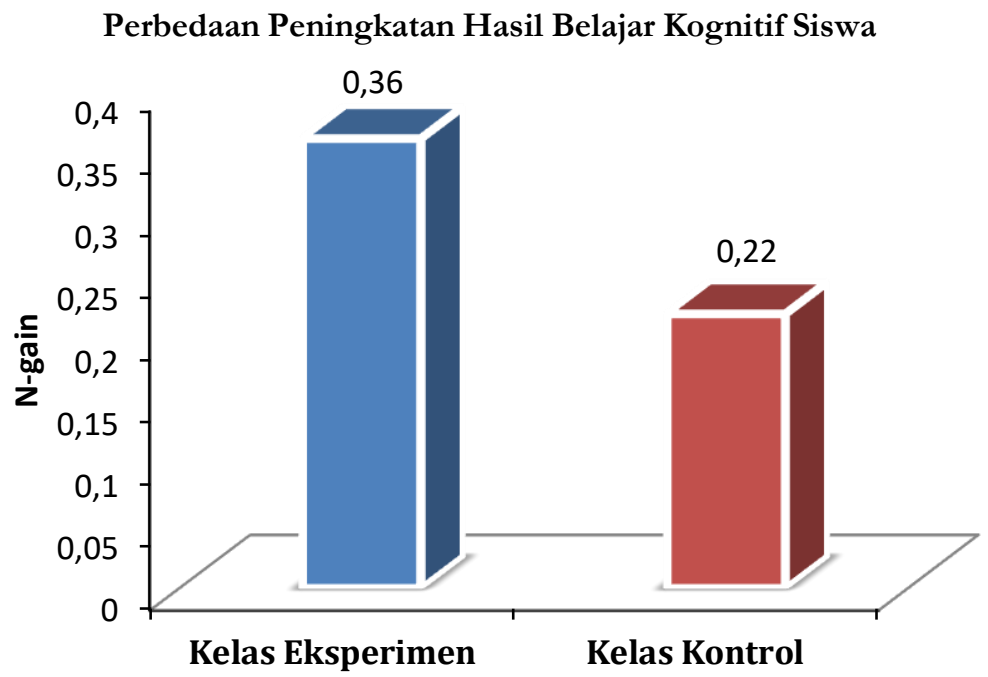

\section{Gambar 1. Perbedaan peningkatan hasil belajar kognitif siswa kelas eksperimen dan kelas kontrol}

Berdasarkan Gambar 1. diketahui bahwa peningkatan hasil belajar kognitif siswa kelas eksperimen yang menggunakan model APPOSITE lebih tinggi daripada peningkatan hasil belajar kognitif siswa kelas kontrol yang menggunakan model direct instruction, hal tersebut disebabkan karena pembelajaran dengan model APPOSITE pada setiap tahap-tahapannya dapat memberikan kesempatan siswa untuk berperan aktif dalam menemukan konsep sendiri misalnya seperti kegiatan praktikum. Selain itu dengan model APPOSITE akan mempermudah siswa dalam memahami konsep fisika karena proses pembelajarannya dihubungkan dengan kejadian dalam kehidupan sehari-hari, hal ini sesuai pendapat Prastowo, (2019) yang menyatakan bahwa desain model pembelajaran APPOSITE didasarkan pada pandangan teori konstruktivisme dengan pendekatan kontekstual yang melibatkan siswa secara aktif serta menghubungkan dengan kehidupan nyata dalam menyelesaikan permasalahan fisika, sehingga melalui model APPOSITE dapat meningkatkan hasil belajar siswa.

Hal ini sesuai penelitian yang dilakukan oleh Ariyanti, (2013), bahwasannya proses pembelajaran yang berpusat pada siswa (student centered) seperti kegiatan praktikum dapat membantu siswa untuk meningkatkan hasil belajar. Serta menurut (Wardani et al., 2009), yang menyatakan bahwa melalui pendekatan keterampilan proses sains seperti kegiatan praktikum dapat meningkatkan hasil belajar siswa. Purwanto, (2014) juga menyatakan bahwasannya peningkatan hasil belajar siswa dipengaruhi oleh faktor internal dan eksternal. Salah satu yang mempengaruhinya yaitu kesempatan siswa terlibat secara langsung dalam proses pembelajaran misalnya dalam melakukan percobaan.

Berdasarkan hasil wawancara setelah pembelajaran dengan salah satu siswa kelas ekperimen menyatakan bahwa pembelajaran dengan model APPOSITE sangat menyenangkan bahkan dalam memahami konsep atau materi yang diajarkan lebih mudah untuk dimengerti, hal ini dikarenakan pada setiap tahapan model APPOSITE dapat melatih siswa untuk ikut aktif dalam proses pembelajaran di kelas misalnya seperti kegiatan praktikum. 


\section{SIMPULAN}

Berdasarkan hasil analisis data diketahui bahwa peningkatan hasil belajar kognitif siswa yang pembelajarannya menerapkan model pembelajaran APPOSITE adalah sebesar 0,36 dengan kategori sedang, sedangkan peningkatan hasil belajar kognitif siswa yang pembelajarannya menerapkan model pembelajaran direct instructions adalah sebesar 0,22 dengan kategori rendah. Selain itu, berdasarkan hasil uji hipotesis menggunakan uji independent sample t-test dapat disimpulkan bahwa terdapat perbedaan yang signifikan antara peningkatan hasil belajar kognitif siswa yang menggunakan penerapan model pembelajaran APPOSITE dengan peningkatan hasil belajar kognitif siswa yang menggunakan penerapan model pembelajaran direct instruction. Model APPOSITE sangat baik diterapkan dalam proses pembelajaran di kelas khususnya pada pelajaran fisika yang harus bisa menguasi konsep dan mampu mengaplikasikannya di kehidupan nyata.

\section{REFERENSI}

Abdurrahman, L., Rusli, A., \& Waldrip, B (2011). Implementasi Pembelajaran Berbasis Multi Representasi untuk Peningkatan Penguasaan Konsep Fisika Kuantum. Cakrawala Pendidikan, 15(1).30-46

Ariyanti, H. (2013). Pengembangan Lembar Kerja Siswa Berbasis Inquiri untuk. Meningkatkan Keterampilan Proses Sains dan Pemahaman Konsep Koloid. (Doctoral Dissertation, Universitas Pendidikan Indonesia.

Astutik, S. (2012). Meningkatkan Hasil Belajar Siswa dengan Model Siklus Belajar (Learning Cycle 5E) Berbasis Eksperimen pada Pembelajaran Sains di SDN Patrang 1 Jember. Jurnal Ilmu Pendidikan Sekolah Dasar, 1(2), 143-153.

Azizirrahim, E., Sutrio, S., \& Gunawan, G. (2017). Penerapan Pendekatan Keterampilan Proses Sains dalam Model Pembelajaran Guided Discovery untuk Meningkatkan Hasil Belajar IPA Fisika pada Siswa Kelas VIIA SMPN 8 Mataram Tahun Ajaran 2015/2016. Jurnal Pendidikan Fisika dan Teknologi, 1(4), 272-275.

Hake, R. R. (1999). Analyzing Change/gain Scores. Indian: Indian University.

Indrawati. (2011). Model-Model Pembelajaran Implementasinya dalam Pembelajaran Fisika. Jember: FKIP Universitas Jember.

Indrawati, S. \&. (2013). Strategi Belajar Mengajar Sains. Jember: University Press Jember.

Jannah, M., Harijanto, A., \& Yushardi, Y. (2019). Aplikasi Media Pembelajaran Fisika Berbasis Sparkol Videoscribe Pada Pokok Bahasan Suhu Dan Kalor Terhadap Hasil Belajar Siswa SMK. Jurnal Pembelajaran Fisika, 8(2), 65-72.

Nurwianti, H., Denny, Y. R., \& Darman, D. R. (2019). Penerapan Model Pembelajaran Interactive Lecture Demonstration (ILD) Menggunakan Simulasi Terhadap Conceptual Change (CC) Pada Materi Momentum dan Impuls. Journal of Natural Science and Integration, 2(2), 163-172. 
Prastowo, S. H. B. (2019). Model Pembelajaran APPOSITE (Application of Step Instruction and Elaboration) untuk. Meningkatkan Penguasaan Konsep Fisika dan Kemampuan Berpikir Kreatif Mabasiswa. Surabaya: UNESA.

Pratama, A. A. (2014). Studi Keterampilan Proses Sains pada Pembelajaran Fisika Materi Getaran dan Gelombang di Kelas VIII SMP Negeri 18 Palembang. Jurnal Inovasi dan Pembelajaran Fisika, 1(2), 137-144.

Prihandono, T. (2011). Efektivitas Metode Belajar Fisika Tanpa Rumus pada Pembelajaran Sains. Jurnal Saintifika, 13(1), 56-67.

Purwanto. (2014). Evaluasi Hasil Belajar. Yogyakarta: Pustaka Pelajar.

Soni, N. Y., Sarwanto, Wahyuningsih, D. (2014). Video Pembelajaran Berbasis Masalah pada Materi Kalor untuk Siswa Kelas VII. Jurnal Pendidikan Fisika, $21(1), 21$.

Sugiyono. (2014). Metode Penelitian Pendidikan Pendekatan Kuantitatif, Kualitatif, dan R\& D. Bandung: Alfabeta.

Wardani, S., Widodo, A. T., \& Priyani, N. E. (2009). Peningkatan hasil belajar siswa melalui pendekatan keterampilan proses sains berorientasi problem-based instruction. Jurnal Inovasi Pendidikan Kimia, 3(1). 391-399

Zahriani, Z. (2014). Kontektualisasi Direct Instruction Dalam Pembelajaran Sains. Lantanida Journal, 2(1), 95-106. 